Terbit online pada laman web jurnal : http://e-journal.sastra-unes.com/index.php/JIPS

\begin{tabular}{|c|c|c|}
\hline & Curnal Ilmiah & (kan Scholastic) \\
\hline $\begin{array}{c}\text { Fakultas Sastra } \\
\text { Universitas Ekasakti }\end{array}$ & $\begin{array}{c}\text { Vol. } 5 \text { No. } 3 \\
\text { ISSN : } 2579-5449 \\
\text { (media cetak) }\end{array}$ & $\begin{array}{c}\text { E-ISSN : } \\
2597-6540 \\
\text { (media online) }\end{array}$ \\
\hline
\end{tabular}

\title{
PENGUATAN BIROKRASI APARATUR NEGARA MENUJU REVOLUSI INDUSTRI 5.0 \\ DI KECAMATAN KOTO TANGAH PADANG SUMATERA BARAT
}

\author{
Edi Hasymi \\ STIE KBP \\ edihasymi@gmail.com
}

\begin{abstract}
Memasuki Revolusi 5.0, pemanfaatan teknologi sudah mulai mempertimbangkan aspek- aspek humaniora terhadap proses penyelesaian masalah yang ada di sektor publik. Oleh karena itu, penelitian ini bertujuan untuk mengetahui penguatan reformasi birokrasi menuju Revolusi Industri 5.0 melalui tata kelola perencanaan pengembangan SDM Aparatur Sipil Negara oleh Camat Kecamatan Koto Tangah Padang. Penguatan reformasi birokrasi menuju Revolusi Industri 5.0 di Kecamatan Koto Tangah Padang mengalami berbagai hambatan terkait masih dominannya patologi birokrasi, budaya korupsi, serta ketidaksiapan birokrasi akan pemanfaatan teknologi dan informasi dalam orientasi pelayanan publik kepada masyarakat. Oleh karena itu, Perencanaan pengembangan SDM Aparatur oleh Camat Kecamatan Koto Tangah dalam memperkuat reformasi birokrasi menuju Revolusi Industri 5.0 harus dilakukan secara tepat dengan merespons berbagai hambatan yang terjadi serta segala bentuk perubahan lingkungan dan perkembangan zaman.
\end{abstract}

Keywords: Aparatur Sipil Negara, Revolusi Industri 5.0

(C) 2021Jurnal JIPS

\section{INTRODUCTION}

Memasuki Revolusi Industri 5.0, implementasi penggunaan teknologi sudah mulai memperhatikan aspek-aspek humaniora guna menciptakan berbagai tools pada proses pemecahan masalah-masalah sosial yang ada (Faruqi, 2019). Tentunya hal ini memerlukan pengelolaan sumber daya manusia (SDM) yang optimal guna mendongkrak kredibilitas organisasi dengan meningkatkan efisiensi masing-masing aparatur birokrasi di bidang informasi, komunikasi, dan teknologi (TIK), dengan tujuan mempermudah pelaksanaan tugas-tugas di masa depan (Rustandi, 2019). Kemudian, Sebagai bagian dari upaya untuk mewujudkan good governance, maka SDM aparatur birokrasi haruslah selalu berorientasi pada pemanfaatan teknologi dalam penyelenggaraan layanan pemerintah, penyederhanaan berbagai regulasi dan juga dalam proses reformasi birokrasi (Mardawani \& Relita, 2019). Pada dasarnya, upaya perbaikan struktural penyelenggaraan pemerintahan di bidang kelembagaan, manajemen, dan sumber daya manusia dikenal dengan reformasi birokrasi (Adlin \& Handoko, 2019; Ferizaldi, 2018). Di mana hadirnya keinginan dalam reformasi birokrasi dapat dipahami sebagai suatu proses untuk menyegerakan perubahan 
menjadi lebih baik dengan tujuan untuk mewujudkan birokrasi penyelenggaraan pemerintahan yang bersih, terbuka, dan akuntabel (Ferizaldi, 2019; Haning, 2018).

Kemudian, Perencanaan sumber daya manusia merupakan landasan untuk menyusun rencana kerja organisasi di divisi kerja sumber daya manusia. Suatu proses yang menjadi bagian penting dalam perencanaan SDM adalah merencanakan pengembangan dengan berkonsentrasi pada pendidikan dan pelatihan, transisi dan promosi, serta mengisi kekosongan jabatan yang membutuhkan tenaga ahli yang berpengalaman (Dzakiyati, 2018; Sudrajat, 2014). Dengan melaksanakan pengembangan SDM maka secara tidak langsung suatu organisasi telah melakukan adaptasi atas perubahan lingkungan dan perkembangan era untuk membangun SDM yang lebih berkualitas, karena dengan hal tersebut maka kinerja organisasi akan semakin meningkat (Sirih et al., 2019). Selain itu, Pengembangan SDM Aparatur Sipil Negara menjadi penting untuk dilakukan karena akan memudahkan lembaga pemerintah baik kecil maupun besar untuk mencapai tujuan mereka yang terkait dengan jumlah pekerja dengan keterampilan yang diperlukan untuk membantu proses organisasi dalam pencapaian tujuan dan sasaran yang diinginkan.

SDM di berbagai jenis institusi publik perlu meningkatkan kompetensi diri dalam manajemen e-resources, manajerial leadership, literasi digital dan research serta melakukan transformasi sebagai persiapan menghadapi perubahan yang semakin cepat dalam mewujudkan masyarakat berpengetahuan (Nashihuddin \& Suryono, 2018). Untuk membangun birokrasi yang cepat dan gesit dalam menyediakan layanan publik diperlukan pembenahan secara struktural (Faedlulloh et al., 2020). Kemudian, Keberlanjutan akan reformasi birokrasi harus tetap dijalankan untuk meningkatkan kualitas pelayanan publik sehingga menyebabkan adanya rasa kepercayaan dari masyarakat terhadap penyelenggaraan pelayanan dari aparatur pemerintah (Purwaningsih et al., 2019). Sehingga, Reformasi birokrasi terkait erat dengan aspek reformasi lainnya seperti pergeseran pola pikir, pengembangan struktur layanan publik berbasis teknologi, serta penyempurnaan regulasi dan kepemimpinan (Hartanto, 2019).

Sistem pemerintahan berbasis elektronik dengan pendekatan bottom-up dapat menjadi alternatif dalam proses pengelolaan yang efektif, efisien, dan transparan. Oleh karena itu adanya inovasi diperlukan untuk adaptasi terhadap perubahan dan pengembangan SDM aparatur pemerintah secara berkelanjutan agar dapat menciptakan inovasi pelayanan publik yang berorientasi terhadap pemanfaatan teknologi informasi (Wardani, 2019). Keinginan publik akan birokrasi yang transparan dan akuntabel, ditambah dengan kondisi lingkungan yang semakin tidak menentu, mendorong pemerintah untuk bereksperimen dengan tata kelola sebagai bagian dari upayanya untuk mereformasi administrasi sektor publik (Kurniati \& Nugroho, 2019). Sehingga revitalisasi birokrasi dalam melakukan transformasi birokrasi yang berorientasi ke arah e-governance dilakukan dengan mengembangkan inovasi, membangun kolaborasi dan sinergi serta memberikan respons atas terjadinya perubahan lingkungan yang sangat cepat (Rahadian, 2019). Selain itu, orientasi pelayanan publik kepada masyarakat tidak hanya berperan untuk peningkatan kinerja birokrasi, akan tetapi juga menjadi unsur strategis dalam mengembangkan pelayanan birokrasi pemerintah di masa depan (Hidayat, 2019). Oleh karena itu, Dalam rangka meningkatkan pembangunan yang berkelanjutan, Aparatur pemerintah harus mampu meningkatkan kompetensi dirinya dalam bidang pengetahuan dan teknologi serta harus memiliki kreativitas untuk mengantisipasi berbagai persoalan baik formal maupun informal (Sakti, 2019), melalui pemanfaatan teknologi kecerdasan yang sudah banyak dilakukan pada sektor publik, untuk memaksimalkan produktivitas hasil kerja yang dilaksanakannya (Yudoprakoso, 2019). Dengan demikian, Penerapan teknologi kecerdasan buatan akan dapat memberikan manfaat untuk membantu memperoleh informasi melalui pengumpulan data yang dapat dijadikan landasan untuk pengambilan keputusan dan perbaikan sistem otomatisasi di masa depan (Saluky, 2018).

Dalam era disrupsi teknologi sampai munculnya revolusi industri 4.0 , aparatur 
pemerintah memainkan peran vital dalam administrasi pemerintahan (Nasution et al., 2019), di mana dalam revolusi industri 4.0 dibutuhkan komitmen dan kesadaran diri untuk membangun budaya birokrasi demi menjaga kepercayaan masyarakat (Rivai, 2019). Untuk membangun sumber daya manusia yang berdaya saing tinggi, diperlukan peningkatan keterampilan, pendidikan dan pelatihan, serta peningkatan budaya kerja (Sihite, 2018). Secara historis, pada era revolusi industri 4.0, berbagai jenis teknologi mengantarkan perubahan budaya kerja manusia menuju era digitalisasi dan otomatisasi (Suwardana, 2018). Kemudian, karena adanya komponen pelengkap yang berbeda, baik era revolusi industri 4.0 maupun Revolusi Industri 5.0 akan dapat mempengaruhi semua aktivitas manusia. Untuk mencapai tujuan Revolusi 5.0 diawali dengan menciptakan "human-centric Revolusi Industri" yang mendorong pembangunan ekonomi masyarakat serta memberikan solusi dalam meningkatkan kualitas hidup masyarakat (Wasitarini, 2019). Ketika di era industri 4.0, semua informasi yang terkumpul melalui jaringan akan dianalisis langsung oleh manusia, memasuki Revolusi 5.0 sebagian besar jumlah informasi dari sensor pada ruang fisik akan diakumulasi menjadi satu dalam cyberspace yang akan dianalisis menggunakan artificial intelligence di mana nantinya hasil analisis tersebut melalui feedback akan diberikan kembali ke manusia yang berada di ruang fisik dalam berbagai macam bentuk yang dihasilkan (Arief \& Saputra, 2019). Oleh karena itu, untuk mendorong tata kelola yang cerdas, kualitas konten harus ditingkatkan, seiring dengan kecepatan publikasi, dengan tetap memperhatikan keakuratan data dan informasi (Maizunati, 2018).

Jika di telusuri kembali, pada dasarnya berbagai tahapan konsep Revolusi Industri bermula dari Revolusi Industri 1.0 yang didefinisikan sebagai sekelompok orang yang berburu dan berkumpul dalam keharmonian dengan alam. Kemudian, Revolusi Industri 2.0 merupakan konsep suatu kelompok budidaya pertanian, kemajuan organisasi, dan pembangunan negara. Selanjutnya, Revolusi Industri 3.0 adalah konsep masyarakat yang mampu mendorong industrialisasi dan memfasilitasi produksi massal melalui revolusi industri. Sedangkan, konsep Revolusi Industri 4.0 akan mengidentifikasi masyarakat informasi yang mewujudkan nilai tambah yang lebih besar dengan menghubungkan aset tidak berwujud melalui jaringan informasi. Kemudian, Revolusi 5.0 saat ini merupakan suatu terobosan konsep masyarakat informasi yang dibangun di atas Revolusi Industri 4.0 dan bertujuan untuk mewujudkan masyarakat yang berpusat pada manusia yang sejahtera di mana setiap orang akan menikmati hidup secara maksimal (Fukuyama, 2018; Harayama, 2016).

Pada intinya, Revolusi Industri 5.0 memiliki tujuan utama yakni untuk menciptakan kesejahteraan melalui pertumbuhan ekonomi dan perkembangan teknologi kepada seluruh lapisan masyarakat (Wasitarini, 2019). Revolusi Industri 5.0 mengacu pada konsep yang menerapkan teknologi pada revolusi industri 4.0 yang memperhatikan aspek humaniora untuk melahirkan cara-cara penyelesaian masalahmasalah sosial (Faruqi, 2019). Kemudian, Revolusi 5.0 adalah suatu bentuk kecerdasan sosial yang secara kuat dapat mengintegrasi antara ruang fisik dan ruang cyber (Salgues, 2018). Dengan demikian, Revolusi Industri 5.0 dapat dipahami sebagai salah satu bentuk kehidupan masyarakat yang menggabungkan data melalui teknologi informasi untuk mendorong peningkatan kecerdasan sumber daya manusia dalam pengembangan berbagai peluang yang dapat dilaksanakan berdasarkan aspek humaniora guna menyelesaikan berbagai persoalan sosial.

Dalam konteks birokrasi di Indonesia, saat ini terlihat dengan jelas bahwa orientasi pelayanan publik masih belum berjalan maksimal karena berbagai faktor yang perlu dibenahi, serta menjadi catatan penting bagi pemerintah untuk terus meningkatkan efisiensi sektor publiknya (Wicaksono et al., 2019; Islah, 2018). Pertama, Masalah korupsi di birokrasi telah menjadi bagian dari feodalisme yang masih terpelihara dalam sistem birokrasi, karena berbagai keputusan publik yang diambil melalui birokrasi pemerintahan tidak pernah lepas dari pola topdown (Hasan, 2012). Kedua, Banyaknya penyuapan yang melibatkan pejabat politik dan pejabat birokrasi menjadi ancaman nyata terhadap nilai budaya luhur bangsa karena bertentangan dengan tujuan negara dalam 
mewujudkan kesejahteraan bagi seluruh masyarakat (Azhary, 2019). Ketiga, masih dominannya patologi birokrasi yang berbelitbelit dalam pelayanan publik dan belum mampu diminimalisir secara optimal. Sehingga, pemahaman secara holistik dan komprehensif oleh aparatur birokrasi terhadap pola hubungan korupsi yang sering terjadi diyakini menjadi penting agar dapat meminimalisasir terjadinya tindak korupsi di sektor pelayanan publik (Hadi, 2016). Selain itu, ketidakmampuan birokrasi dalam mendukung terciptanya Revolusi Indutri 5.0 juga merupakan dinamika yang begitu kompleks di Indonesia (Kumorotomo, 2019; Sugiono, 2020). Hal ini dikarenakan di Revolusi 5.0 birokrasi di Indonesia harus mampu memahami berbagai pemanfaatan big data sebagai sumber informasi yang didukung oleh teknologi dan kesiapan para aktor dalam proses pembuatan kebijakan serta juga harus memperhatikan aspek-aspek kemanusiaan lainnya bagi masyarakat (Rahmanto et al., 2021).

\section{RESEARCH METHOD}

Penelitian ini menggunakan metode penelitian kualitatif (Aspers \& Corte, 2019), yang bertujuan untuk mengetahui terkait bagaimana tata kelola perencanaan pengembangan SDM Aparatur dalam memperkuat reformasi birokrasi untuk merespons terjadinya segala perubahan lingkungan dan perkembangan masyarakat menuju Revolusi Industri 5.0 oleh Aparatur Sipil Negara. Oleh karena itu, Penelitian ini akan memberikan penjelasan mengenai tata kelola perencanaan pengembangan SDM Aparatur untuk memperkuat reformasi birokrasi menghadapi perubahan era menuju Revolusi

\section{RESULTS AND DISCUSSION}

Seiring dengan laju perkembangan teknologi dan penciptaan inovasi, pada prosesnya tata kelola pemerintahan yang baik di Indonesia belum dapat diadopsi dalam kehidupan masyarakat sehari-hari karena tidak ada platform yang disiapkan dalam menuju Revolusi 5.0 (Sugiono, 2020). Penelitian (Saksono \& Manoby, 2021), menjelaskan bahwa tata kelola pemerintahan di Indonesia belum dapat berjalan secara optimal untuk mendorong terwujudnya Revolusi 5.0. Selain itu, penelitian ini juga memberikan beberapa rekomendasi yaitu peningkatan infrastruktur internet yang menjangkau wilayah pelosok, penyiapan legal framework, kerja sama lembaga negara dan korporasi, dan penguatan kebijakan inovatif berbasis riset yang mendukung terciptanya birokrasi menuju Revolusi Industri 5.0 di Indonesia.
Industri 5.0 di mana pemanfaatan teknologi untuk meningkatkan kinerja SDM akan tetap mempertimbangkan aspek humanisme dalam setiap penyelesaian masalah sosial. Kemudian, Data dalam penelitian ini dikumpulkan dengan menggunakan teknik literature review yaitu metode pengumpulan informasi penelitian dari berbagai buku dan jurnal yang relevan dengan fokus studi (Farida, 2019. Berikutnya, dilakukan penarikan kesimpulan yang merupakan hasil akhir dari analisis data dengan melakukan interpretasi melalui refleksi terhadap data penelitian (Gumilang, 2016).

Implementasi reformasi birokrasi SDM Aparatur mempunyai peran strategis dan penting sebagai bagian dalam mendukung kelancaran pembangunan nasional, sehingga tanpa adanya reformasi birokrasi yang baik maka setiap target yang telah ditetapkan untuk mencapai pembangunan nasional akan sulit tercapai. Oleh karenanya dalam reformasi birokrasi penting untuk terus melakukan perbaikan-perbaikan melalui berbagai macam regulasi, modernisasi kebijakan tata kelola SDM Aparatur di tingkat pusat dan daerah dengan menyesuaikan tugas fungsi organisasi pemerintah atas terjadinya perubahan era yang cepat. Sebagai upaya dalam mewujudkan good governance dapat dilakukan melalui peningkatan SDM Aparatur, dan melakukan integrasi pemanfaatan teknologi untuk penyelenggaraan layanan pemerintah, 
penyederhanaan berbagai regulasi dan reformasi birokrasi (Mardawani \& Relita, 2019)

Reformasi birokrasi SDM Aparatur yang dilakukan harus mampu menyesuaikan dengan setiap dimensi perubahan penyelenggaraan pemerintahan untuk mewujudkan pembangunan nasional. Reformasi birokrasi SDM Aparatur menjadi prasyarat dasar untuk menciptakan kualitas SDM pemerintahan yang unggul, lebih profesional, berkinerja tinggi, bersih dan akuntabel sehingga mampu menghadapi segala bentuk perubahan perkembangan global dimasa mendatang. SDM Aparatur yang mampu melaksanakan tugastugas penyelenggaraan pemerintahan, konstruksi, dan pelayanan publik sangat dibutuhkan guna mengikuti perkembangan zaman dan teknologi, serta kondisi yang semakin kompetitif di segala aspek kehidupan sosial. Melalui SDM Aparatur yang semakin berkualitas maka dapat memberikan kontribusi optimal kepada publik serta menjadikan organisasi pemerintah yang unggul dalam menyesuaikan terhadap perubahan global dan tuntutan dari publik. Sehingga tata kelola sumber daya manusia diperlukan untuk meningkatkan kredibilitas organisasi pemerintah melalui pengembangan SDM Aparatur dengan berorientasi kompetensi terhadap ICT yang berperan penting mendukung pelaksanaan tugas dimasa depan (Rustandi, 2019).

Melalui tata kelola perencanaan pengembangan SDM Aparatur yang terstruktur dengan baik, maka dimasa depan akan dapat menciptakan birokrasi Revolusi 5.0 yang merupakan suatu konsep birokrasi pemerintah dengan kualitas SDM Aparatur yang unggul pengetahuan, unggul ketrampilan dan unggul sikap dan mental. Menyesuaikan dengan perubahan dan perkembangan era maka sudah menjadi kewajiban bagi aparatur pemerintah memiliki keunggulan dalam pengetahuan yang berarti mampu mengetahui perkembangan informasi pengetahuan baik dari tingkat lokal, nasional maupun internasional. Kemudian unggul dalam keterampilan artinya dengan kompetensi yang dimiliki mampu memanfaatkan segala bentuk sarana prasarana teknologi untuk mendukung kelancaran tugas dan fungsi pekerjaan yang ada. Unggul dalam sikap mental artinya setiap pegawai pemerintah dalam menjalankan tugas dan fungsinya yang didukung dengan pemanfaatan teknologi tetap memperhatikan sisi humanisme ketika memberikan pelayanan kepada masyarakat dalam rangka pengambilan peran sebagai problem solving untuk segala bentuk permasalahan sosial yang terjadi akibat perubahan era yang menyebabkan timbulnya kompleksitas permasalahan di sektor publik. Sehingga birokrasi Revolusi Industri 5.0 yang merupakan birokrasi masa depan sangat membutuhkan pengembangan ilmu pengetahuan yang didukung oleh pemanfaatan teknologi dan SDM Aparatur pemerintah yang berkompeten secara bersama-sama untuk dapat berkontribusi secara optimal terhadap berbagai sektor kehidupan sosial masyarakat (Faruqi, 2019).

Adanya tuntutan dari masyarakat dan tuntutan perkembangan era baik di tingkat nasional maupun global terhadap kualitas kompetensi dari SDM Aparatur pemerintah yang profesional dalam melaksanakan tugas dan fungsi pemerintahan, pembangunan serta pelayanan masyarakat menjadikan urgensi reformasi birokrasi SDM Aparatur sebagai suatu hal yang tidak bisa ditunda lagi. Oleh karena itu, perlu dibangun suatu tata kelola perencanaan pengembangan SDM Aparatur pemerintah yang baik untuk mendukung ketersediaan sumber daya manusia yang memiliki profesionalitas, berkinerja tinggi serta unggul dalam bidang pengetahuan, keterampilan dan sikap mental pada masa mendatang. Berdasarkan pada kondisi tersebut maka sudah seharusnya SDM di berbagai jenis institusi publik perlu meningkatkan kompetensi diri dalam manajemen e-resources, manajerial leadership, literasi digital serta melakukan transformasi kepemimpinan sebagai upaya dalam mengubah birokrasi untuk menghadapi tantangan pembaruan dan tuntutan perubahan era (Nashihuddin \& Suryono, 2018; Umam, 2019).

Tata Kelola SDM Aparatur Menuju Birokrasi Revolusi 5.0

Sebagai instrumen penting dalam tata kelola SDM Aparatur, maka salah satu upaya yang dilakukan oleh Kementrian untuk memperkuat reformasi birokrasi adalah melalui perencanaan pengembangan sumber daya manusia. Dalam orientasinya, pelaksanaan 
perencanaan pengembangan SDM Aparatur bertujuan untuk menghasilkan PNS yang berkualitas, memiliki nilai-nilai fundamental, kompetensi profesional, bebas intervensi politik, dan tidak terlibat dalam praktik kolusi maupun nepotis. Aparatur pemerintah sebagai suatu disiplin ilmu diharapkan dapat mengelola dan meningkatkan diri, serta mempertanggungjawabkan keberhasilannya melalui penggunaan kerangka kerja sistem merit (berbasis kompetensi) dalam pelaksanaan pengelolaan SDM bagi aparatur pemerintah. Dengan demikian, Kompetensi memainkan peran penting dalam menumbuhkan produktivitas SDM di periode kemajuan teknologi yang memungkinkannya untuk berperan dalam mencapai tujuan organisasi (Sihite, 2018).

Kemudian, Revitalisasi birokrasi SDM Aparatur yang dilakukan dengan transformasi birokrasi ke arah e-governance melalui pengembangan inovasi, membangun kolaborasi dan sinergi serta dengan memberikan respons atas terjadinya perubahan lingkungan yang sangat cepat dan perkembangan era teknologi (Rahadian, 2019). Dengan terwujudnya birokrasi Revolusi Industri 5.0 melalui tata kelola perencanaan pengembangan SDM Aparatur yang berbasis kompetensi maka diharapkan adanya perbaikan dalam hal sejauh mana aparatur pemerintah bebas dari korupsi, kolusi, dan nepotisme. Pasalnya, tindakan korupsi telah mengakibatkan pelanggaran hak ekonomi dan sosial masyarakat yang dapat menimbulkan masalah sosial, ekonomi, dan kesejahteraan (Azhary, 2019). Birokrasi Revolusi Industri 5.0 akan mendorong produksi layanan publik berkualitas tinggi untuk kebutuhan negara yang sedang berjuang melawan dinamika global yang lebih ketat. Selain itu, kapasitas dan tanggung jawab birokrasi untuk keberhasilannya akan meningkat, dan pola pikir serta budaya yang mewakili integritas dan kinerja akan semakin meningkat di masa depan.

Hal ini akan menghasilkan birokrasi pemerintahan yang kuat dan akan mendorong terlaksananya kebijakan dan program pembangunan nasional yang terintegrasi dengan mempertimbangkan keterkaitan antara faktor ekonomi, sosial, dan lingkungan. Pengembangan SDM Aparatur yang berorientasi terhadap keunggulan kompetensi pengetahuan dan keterampilan akan dapat mengelola ICT yang terintegrasi dengan aman dan andal. Sedangkan pengembangan aparatur pemerintah yang unggul sikap mental dapat mengelola pelayanan dengan inovatif, adaptif dan responsif melalui sikap humanis terhadap segala bentuk perubahan dan keinginan kebutuhan masyarakat. Tata kelola pengembangan SDM diperlukan dengan meningkatkan kompetensi aparatur negara terhadap pemanfaatan ICT sehingga dapat berkontribusi secara optimal untuk mewujudkan good governance (Faruqi, 2019; Mardawani \& Relita, 2019; Rustandi, 2019).

Menuju Birokrasi Revolusi Industri 5.0

Perkembangan era dan teknologi yang semakin cepat telah mendorong birokrasi untuk melakukan perubahan melalui tata kelola pengembangan SDM Aparatur. Sumber daya manusia sebagai penggerak dan dinamika pemerintahan berada pada garda terdepan dalam melakukan perubahan dalam mewujudkan aparatur negara yang kompeten, yaitu aparatur SDM yang memiliki keahlian dan keterampilan manajerial yang unggul, guna mempercepat pembangunan tata pemerintahan yang baik. Karena dinamika perubahan lingkungan yang semakin membutuhkan kemampuan analitis untuk menghasilkan informasi, maka penting dilakukan pengembangan SDM birokrasi pemerintahan dengan meningkatkan keterampilan belajar yang berkelanjutan (Gunastri, 2013). Dalam rangka meningkatkan proses pembangunan berkelanjutan, motivasi bagi pegawai untuk terus belajar dan menambah pengetahuannya tentang pekerjaan di unit lainnya akan membuat seorang pegawai tidak hanya menguasai satu bidang saja, akan tetapi dapat menguasai dan tahu bagaimana melaksanakan pekerjaan di semua bidang. Diperkuat dengan keterampilan ICT, literasi pengetahuan dan literasi media, serta pemahaman tentang data besar dan kecerdasan buatan (Arief \& Saputra, 2019).

Dewasa kini, Pemerintah sudah mestinya harus fokus pada pengembangan SDM Aparatur yang memiliki pengetahuan dan kemampuan teknis yang signifikan dan relevan secara substansial dan kontekstual dengan perkembangan zaman. Pengetahuan substansial 
yakni penguasaan pengetahuan yang meliputi kemampuan kognitif dan analitik. Sedangkan pengetahuan kontekstual yakni kemampuan SDM dalam memahami kondisi lingkungan organisasi baik lingkungan alam, sosial, budaya, dan iklim kerja. Tidak hanya itu, Birokrasi juga harus mampu mengadopsi teknologi dan memiliki pengetahuan terkait big data yang terintegrasi ke semua unit yang ada di birokrasi. Sehingga diperlukan internalisasi budaya akademis ke dalam birokrasi agar SDM Aparatur memiliki mental pembelajar dan termotivasi meningkatkan pengetahuan serta kemampuannya dalam memanfaatkan teknologi. Selain itu SDM Aparatur di masa depan harus memiliki keterampilan mental, keterampilan sosial, dan keterampilan manual. Keterampilan mental, yaitu penguasaan atas keahlian seseorang dalam menghadapi fenomena dan kejadian yang muncul di sekitar dunia, serta kemampuan untuk melakukan kajian yang akurat terhadap peristiwa yang terjadi. Keterampilan sosial, yaitu kemampuan untuk bergaul dengan orang lain dan bisa saling berkolaborasi. Sementara itu, keterampilan manual mengacu pada kemampuan seseorang untuk menggunakan anggota tubuh dan indranya untuk menghasilkan barang dan jasa kreatif yang bernilai tinggi dan berorientasi pada inovasi. Pada prosesnya, Inovasi diperlukan untuk adaptasi terhadap perubahan dan pengembangan SDM aparatur pemerintah agar mampu menciptakan inovasi pelayanan publik yang berorientasi terhadap pemanfaatan teknologi informasi (Wardani, 2019). Dengan demikian, keterampilan dan kemampuan spesifik aparatur pemerintah dapat menjadi landasan bagi pengembangan pola pikir profesional seperti yang ditunjukkan oleh kapabilitasnya dalam mengidentifikasi kebutuhan masyarakat, menetapkan tujuan, dan memprioritaskan program berdasarkan kebutuhan dan harapan masyarakat. Alhasil, birokrasi akan lebih mampu merespons setiap persoalan yang muncul, menunjukkan fleksibilitas dalam segala keadaan, dan menjaga kepercayaan publik. Sehingga, Adanya komitmen dan kesadaran diri sangat dibutuhkan oleh setiap aparatur pemerintah untuk membangun budaya birokrasi agar tidak kehilangan kepercayaan publik (Rivai, 2019).

Birokrasi Revolusi Industri 5.0 selain memiliki keunggulan pengetahuan dan keterampilan dalam memanfaatkan teknologi juga harus unggul dalam sikap mental. Profesionalisme SDM aparatur tidak hanya sebatas keahlian dalam berteknologi dan pengetahuan tinggi, tetapi harus diimbangi dengan perilaku yang beretika moral. Hal ini karena SDM aparatur bukan hanya bekerja untuk kepentingan individu, tetapi juga untuk kepentingan masyarakat. Dibutuhkan perubahan budaya birokrasi yang responsif dan aspiratif dalam merespons setiap bentuk tuntutan publik sehingga SDM Aparatur perlu melakukan internalisasi nilai-nilai tersebut ke dalam sikap mental perilaku aparatur birokrasi yang memberikan pelayanan kepada masyarakat. Perubahan pola pikir dan sikap mental SDM terhadap modernitas dalam birokrasi Revolusi Industri 5.0, ke depannya harus mampu menghasilkan birokrasi dengan budaya kerja yang berkelanjutan, efektif, manusiawi, disiplin, dan kompeten (Sihite, 2018). Hal ini menjadi dasar dari upaya mengintegrasikan tata kelola sumber daya manusia ke dalam tata kelola yang dinamis berdasarkan prinsip pemikiran antisipatif, reflektif, dan kreatif yang menguntungkan organisasi pemerintah. Sehingga mereka tidak hanya memiliki posisi yang baik secara kelembagaan untuk menangani isu-isu publik, tetapi juga memiliki modal mental untuk menghadapi potensi tantangan dan meningkatkan kepercayaan publik. 


\section{CONCLUSION}

Berdasarkan hasil dan pembahasan di atas dapat diketahui bahwa penguatan reformasi birokrasi dalam penciptaan SDM aparatur menuju Revolusi 5.0 di Kecamatan Koto Tangah Padang telah dilakukan oleh Aparatur Sipil Negara melalui sistem merit yang membandingkan keterampilan dan kompetensi suatu jabatan pada tahap rekrutmen, pengangkatan, dan promosi, dengan tetap mempertimbangkan aspek integritas dan moralitas. Namun, penguatan reformasi birokrasi menuju Revolusi Indutri 5.0 di Indonesia mengalami berbagai hambatan terkait masih dominannya patologi birokrasi, budaya korupsi, serta ketidaksiapan birokrasi akan pemanfaatan teknologi dan informasi dalam orientasi pelayanan publik kepada masyarakat. Oleh karena itu, Perencanaan pengembangan SDM Aparatur Sipil Negara dalam memperkuat reformasi birokrasi menuju Revolusi Industri 5.0 harus dilakukan secara tepat dengan merespons berbagai hambatan yang terjadi serta segala bentuk perubahan lingkungan dan perkembangan zaman. 


\section{Bibliography}

[1]Adlin, T. H. (2019). Penguatan Perilaku Anti Korupsi di Lingkungan Birokrasi Pemerintah Provinsi Riau. Nakhoda: Jurnal Ilmu Pemerintahan, 17(29), 4655.https://doi.org/10.35967/jipn.v17i29. 7058

[2]Alekseev-Apraksin, A., \& Bertova, A. (2021). Leader 'S Strategy in Super Smart Digital Revolusi Industri. Proceedings of the 1st International Scientific Conference "Legal Regulation of the Digital Economy and Digital Relations: Problems and Prospects of Development" (Larder 2020), 171, 207-214.

[3]Annisah. (2017). Usulan Perencanaan Smart City: Smart Governance Pemerintah Daerah Kabupaten Mukomuko. Jurnal Masyarakat Telematika dan Informasi, $8(1)$, 59-80 https://doi.org/10.17933/mti.v8i1.103

[4]Arief, N. N., \& Saputra, M. A. A. (2019). Kompetensi Baru Public Relations Pada Era Artificial Intelligence. Jurnal Sistem Cerdas, 2(1), 1-12. https://doi.org/10.37396/jsc.v2i1.19

[5]Azhary, V. H. (2019). Nepotisme dan Gratifikasi Sebagai Unsur Budaya Pada Korupsi Politik dan Birokrasi di Indonesia. Simposium Nasional Ilmiah Dengan Tema: (Peningkatan Kualitas Publikasi Ilmiah Melalui Hasil Riset Dan Pengabdian Kepada Masyarakat), 754 762. https://doi.org/10.30998/simponi.v0i0.4 37

[6]Baskoro Wicaksono, Nur Laila Meilani, R. F. (2019). Perencanaan Pembangunan Kabupaten Bengkalis Aspek Kebudayaan Melayu Dalam Menopang Visi Provinsi Riau 2020. Nakhoda: JurnalIlmuPemerintahan, 17(29),22-34. https://doi.org/https://doi.org/10.35967/ jipn.v17i29.7056

[7]Dodi Faedlulloh, Yulianto, V. K. (2020). A Structural And Mindset Bureaucratic Reform Agenda For Jokowi's Second Term. Bisnis \& Birokrasi: Jurnal Ilmu Administrasi dan Organisasi, 27(2), 67-77.
Https://Doi.Org/10.20476/Jbb.V27i2.11 466

[8]Dzakiyati, F. (2018). Modifikasi Perilaku Aparatur Ala Skinner: Suatu Model Pengembangan Sumber Daya Manusia Menuju Profesionalisme Birokrasi. Jurnal Ilmiah Tata Sejuta STIA Mataram, 4(1), 13-26. https://doi.org/10.32666/tatasejuta.v4i1. 29

[9]Fajar Rahmanto, Ulung Pribadi, A. P. (2021). Big Data: What Are The Implications For Public Sector Policy In Revolusi Industri 5.0 Era? Iop Conference Series: Earth And Environmental Science 717, 1-7. https://doi.org/10.1088/17551315/717/1/012009

[10]Farida, A. (2019). Studi Pustaka Tentang Perkembangan Teknologi dan Peningkatan Kepatuhan Pajak: Apakah Berbanding Lurus? Moneter - Jurnal Akuntansi Dan Keuangan, 6(2), 135140.https://doi.org/10.31294/moneter.v $6 \mathrm{i} 2.6183$

[11]Ferizaldi. (2018). Patologi Birokrasi Dalam Transformasi Politik Lokal: Tinjauan Terhadap Fenomena "Pajak Nanggroe" Di Aceh. Nakhoda: Jurnal Ilmu Pemerintahan, 16(27), 32-39. https://doi.org/https://doi.org/10.35967/ jipn.v16i27.5793

[12]Ferizaldi. (2019). Model Akuntabilitas Birokrasi di Era Otonomi Khusus Aceh (Tinjauan Terhadap Tes Shalat dan Baca Al-Qur'an di Kabupaten Aceh Barat Daya). Nakhoda: Jurnal Ilmu Pemerintahan, 17(29), 14-21. https://doi.org/10.35967/jipn.v17i29.70 55

[13]Fujii, T., Guo, T., \& Kamoshida, A. (2018). A Consideration Of Service Strategy of Japanese Electric Manufacturers to Realize Super Smart Revolusi Industri (Revolusi Industri 5.0) (Vol. 2). Springer International Publishing. https://doi.org/10.1007/978-3-31995204-8

[14]Gumilang, G. S. (2016). Metode Penelitian Kualitatif Dalam Bidang Bimbingan dan

Jurnal JIPS (Jurnal Ilmiah Pendidikan Scholastic ) Vol. 5 No. 3 (2021) ISSN : 2579-5449

This work is licensed under a Creative Commons Attribution-NonCommercial 4.0 International License. 
Konseling. Jurnal Fokus Konseling, 2(2), 144-159.

[15]Hadi, K. (2016). Korupsi Birokrasi Pelayanan Publik di Era Otonomi Daerah. Jurnal Penelitian Politik, 5170.

[16]Haning, M. T. (2018). Reformasi Birokrasi di Indonesia: Tinjauan Dari Perspektif Administrasi Publik. Jurnal Analisis Kebijakan dan Pelayanan Publik, 4(1), 25-37.

[17]Hartanto, D. (2019). Kajian Wilayah Birokrasi Bersih dan Melayani Kepolisian Resort Kota Medan. Publikauma: Jurnal Ilmu Adminstrasi Publik, 7(2), 71-87. http://dx.doi.org/10.31289/publika.v7i2 .2805

[18]Hasan, N. (2012). Corak Budaya Birokrasi Pada Masa Kerajaan, Kolonial Belanda Hingga di Era Desentralisasi Dalam Pelayanan Publik. Jurnal Hukum, 28(2), 1073-1087.

[19]Hidayat, E. S. (2019). Kinerja Pelayanan Birokrasi Dalam Mewujudkan Kepuasan Pelanggan. Dinamika: Jurnal Ilmiah Ilmu Administrasi Negara, 6(2), 43-49.

http://dx.doi.org/10.25157/dinamika.v6 i2. 2260

[20]Islah, K. (2018). Peluang dan Tantangan Pemanfaatan Teknologi Big Data Untuk Mengintegrasikan Pelayanan Publik Pemerintah. Jurnal Reformasi Administrasi, 5(1), 130- 138.

[21]Kumorotomo, W. (2019). Envisioning Agile Government: Learning From the Japanese Concept of Revolusi Industri 5.0 and the Challenge of Public Administration in Developing Countries. Advances In Economics, Bussines And Management Research: Annual Conference of Indonesian Association For Public Administration (IAPA 2019), 122, 144-163.

[22]Kurniati, P. N., \& Nugroho, B. Y. (2019). The Urgency Of The Implementation Of The Cashless Government System In Building A Transparent And Accountable Bureaucracy. Jurnal Administrasi Publik, 9(2), 136-150. http://dx.doi.org/10.31289/jap.v9i2.265 5

[23]Maizunati, N. A. (2018). Implementasi Data Sektoral Terbuka Dalam Mendukung Smart Governance Di Kota Magelang. Journal of Public Administration and Local Governance, 2(2), 31. https://doi.org/10.31002/jpalg.v2i2.1082

[24]Mardawani, \& Relita, D. T. (2019). Strategi Pemerintah Daerah Kabupaten Sintang Dalam Mewujudkan Visi Pemerintahan dan Good Governance. Jurnal Ilmiah Pendidikan Pancasila dan Kewarganegaraan, 4(1), 109-116.

[25]Nashihuddin, W., \& Suryono, F. (2018). Tinjauan Terhadap Kesiapan Pustakawan Dalam Menghadapi Disrupsi Profesi di Era Library 4.0: Sebuah Literatur Review. Khizanah AlHikmah: Jurnal Ilmu Perpustakaan, Informasi, dan Kearsipan, 6(2), 86. https://doi.org/10.24252/kah.v6i2a1

[26]Nasution, D. A. D., Nasution, A. P., \& Alpi, M. F. (2019). Pengaruh Penerapan Smart Asn Terhadap Pengelolaan Keuangan Negara Di Era Disrupsi Teknologi Indonesia 4.0. Seminar Nasional Sains \& Teknologi Informasi, 43-51.

[27]Patrik Aspers, U. C. (2019). What Is Qualitative In Qualitative Research. Qualitative Sosiology, 42(2), 139-160. https://doi.org/https://doi.org/10.1007/s 11133-019-9413-7

[28]Purwaningsih, A. S., Afifuddin, \& Abidin, A. Z. (2019). Reformasi Birokrasi Pelayanan Publik Dalam Meningkatkan Kualitas Pelayanan Publik Studi Kasus Pada Pelayanan Kartu Keluarga di Dinas Kependudukan dan Pencatatan Sipil Kabupaten Malang. Jurnal Respon Publik Volume, 13(4), 82-86.

[29]Rustandi. (2019). Kinerja Manajemen Sumber Daya Manusia di Era Disrupsi. Kebijakan: Jurnal Ilmu Administrasi, 10(2), 67-73.

[30]Sakti, B. (2019). Kompetensi Aparatur Pemerintah Daerah Dalam Sumber Daya Manusia di Era Reformasi. Pareto: Jurnal Ekonomi dan Kebijakan Publik, $2(1), 35-44$. 
[31]Salgues, B. (2018). Revolusi Industri 5.0 Industry of the Future, Technologies, Methods and Tools. London: ISTE Ltd.

[32Saluky. (2018). Tinjauan Artificial Intelligence Untuk Smart Government. Itej (Information Technology Engineering Journals), 03(01), 1-9.

[33]Sihite, M. (2018). Peran Kompetensi Dalam Mewujudkan Sumber Daya Manusia Yang Berdaya Saing Tinggi di Era Revolusi Industri 4.0: Suatu Tinjauan Konseptual. Jurnal Ilmiah Methonomi Volume, 4(2), 145-159.

[34]Sirih, S. H., Ismail, I., \& Juharni. (2019). Development Strategies Of Human
Resources In Bkpsdm Majene District. Jurnal Paradigma, 1(2), 1-6.

[35]Sudrajat, T. (2014). Eksistensi Kebijakan Pengisian Jabatan Struktural Dalam Kerangka Pengembangan Sdm Aparatur Berbasis Merit. Jurnal Kebijakan dan Manajemen PNS, 8(1), 61-72.

[36]Sugiono, S. (2020). Digital Content Industry In Revolusi Industri 5.0 Perspective. Jurnal IPTEK-KOM (Jurnal Ilmu Pengetahuan dan Teknologi Komunikasi), 22(2), 175-191. 